\title{
Effect of limestone catalyst on co-gasification of coconut fronds and wood chips
}

\author{
Muddasser Inayat $^{1}{ }^{*}$, Shaharin A. Sulaiman ${ }^{1}$, Tham W. Hung ${ }^{1}$, Fiseha M. Guangul ${ }^{3}$, and \\ Firdaus Basrawi ${ }^{2}$ \\ ${ }^{1}$ Department of Mechanical Engineering, Universiti Teknologi PETRONAS, 32610 Bandar Seri \\ Iskandar, Perak Darul Ridzuan, Malaysia. \\ ${ }^{2}$ Faculty of Mechanical Engineering, Universiti Malaysia Pahang, 26600 Pekan, Pahang, Malaysia. \\ ${ }^{3}$ Department of Mechanical Engineering, Middle East College, Knowledge Oasis Muscat, P.B. No. \\ 79, Al Rusayl, Postal Code: 124, Muscat, Sultanate of Oman
}

\begin{abstract}
Biomass energy via gasification is an attractive substitute of fossil fuels. The distribution of biomass on the earth is scattered, so transportation and collection of biomass complicates the supply of biomass especially when the gasification rely on one type of biomass. Therefore, cogasification of different biomass is proposed as a potential solution for interruption-free gasification. Beside, unwanted by-products such as tar that cause blockage in downstream equipment can be minimized through the use of catalyst in gasification to accelerate tar reforming process. In this study, catalytic co-gasification of blended feedstock of $70 \%$ wood chips and $30 \%$ coconut fronds was carried out in a downdraft gasifier using limestone as primary catalyst. The effects of catalyst loading $(0 \%, 30 \%, 50 \%$, and $70 \%$ $\mathrm{w} / \mathrm{w})$ on syngas composition, gas yield, carbon conversion efficiency and heating value of syngas were investigated. The results showed that at $50 \%$ biomass to catalyst ratio, maximum $\mathrm{H}_{2}$ content of $11.39 \%$, $\mathrm{CO}$ of $17.88 \%$, carbon conversion efficiency of $69.49 \%$, gas yield of $1.68 \mathrm{Nm}^{3} / \mathrm{kg}$ and higher heating value of syngas $5.11 \mathrm{MJ} / \mathrm{Nm}^{3}$ were achieved. Higher catalyst loading $(70 \%)$ blocked the air passage, which caused poor gasification. No more than $50 \%$ catalyst suggested for stable co-gasification operation.
\end{abstract}

\section{Introduction}

Energy demand has been growing for the past several decades due to rapid industrial and urban development, meanwhile fossil fuel reserves have been in decline. Biomass energy is a popular alternative to substitute fossil fuels [1-3]. Malaysia provides a huge quantity of biomass resources such as agricultural wastes, forest residues and urban wastes [4].

However, certain types of biomass are very sensitive to weather and temperature, thus required supply of feedstock throughout the year become a major problem for gasification operation specially when operation is dependent on only one type of biomass. Interruption of biomass supply, consequently affects the reliability of the gasification operation. Moreover, gasifiers are normally designed for one type of biomass gasification. In addition, not all

*Corresponding author: muddasser_engr@yahoo.com 
biomass materials are suitable to gasify using downdraft gasifier due to their different physical nature such as density, particle size, shape etc. The combination of various forestry and agricultural wastes as feedstock for gasification provides higher operation flexibility and minimizes problem associated with the effect of seasonal supply variations [5]. Many researchers co-gasified coal and biomass at various blending ratios [6, 7]. However, the studies on co-gasification of two different biomass materials are very limited [8-11].

Biomass can be converted into synthesis gas via gasification. Biomass gasification is the partial combustion which converts the of solid biomass fuel into useful gases and chemical through a series of chemical reactions [12]. The syngas produced from biomass gasification are mainly consists of hydrogen, carbon monoxide, methane, carbon dioxide, water vapor and nitrogen. The yield of products of gasification is dependent on several parameters, which include temperature, biomass species, particle size, and reactor type as well as addition of catalyst $[1-3,10,13,14]$. From the past studies, it is found that the gas yield, especially $\mathrm{H}_{2}$ could be improved by adding catalyst together with, by improving the higher heating value of the synthesis gases [11,15-17]. Many studies have been attempted to introduce the mineral catalyst in biomass gasification especially calcium based catalyst including $\mathrm{CaO}$ and $\mathrm{CaCO}_{3}$ limestone and concrete waste $[18,19]$. Limestone shows moderate performance, especially for heavy tar reforming. Past researches also indicated that the calcium based catalyst can facilitate the reaction rate, increase the syngas production and lower the by-product output so as to increase the economic feasibility of the biomass gasification [16]

In this study, air catalytic co-gasification of coconut fronds and wood chips was performed in downdraft gasifier. The effect of catalyst loading was investigated on syngas composition, gas yield, syngas heating value, and carbon conversion efficiency.

\section{Materials and Methodology}

\subsection{Characterization and Preparation of Feedstock}

Wood (acacia mangium) and coconut (cocos nucifera) fronds were considered potential feedstock for the present study. Wood logs were collected from the landscape area of Universiti Teknologi PETRONAS, Malaysia during trimming activities. These logs were chipped down using a wood shredder at the wood factory. The coconut fronds (CF) were collected from Teluk Intan, Perak, Malaysia. The fronds were cut down using a power circular saw. Ultimate and proximate analyses of feedstock were determined according to ASTM (American Society of Testing Materials) D3176-09 and ASTM E1755-01, respectively. Leco AC-350 bomb calorimeter was used for determined higher heating values of the feedstock according to ASTM D4809-00 standard procedure. The wood chips (WC) and $\mathrm{CF}$ were sieved to particle sizes ranging between $10-25 \mathrm{~mm}$ and were mixed at the blending ratio of $70 \% \mathrm{WC}$ and $30 \% \mathrm{CF}$ on mass basis. The moisture content of feedstock was determined according to ASTM E871-82 standard test method. The characterization results of the feedstock are presented in Table 1. Natural limestone was used as catalyst and it was collected from Ipoh, Perak, Malaysia. Elemental analysis of limestone are shown in Table 2 [20] Limestone has a high $\mathrm{CaO}$ up to $70.91 \%$. Before using limestone as a catalyst, it was calcined at $900^{\circ} \mathrm{C}$ for 4 hours.

Table 1. Thermochemical properties of wood chips (WC) and coconut fronds (CF).

\begin{tabular}{|l|l|l|l|l|l|l|l|l|l|l|}
\hline \multirow{2}{*}{ Biomass } & \multicolumn{4}{|l|}{ Ultimate Analysis (wt. \%) } & \multicolumn{4}{|c|}{ Proximate Analysis (wt. \%) } & HHV \\
\cline { 2 - 11 } & C & H & O* & S & N & VM & FC & Ash & MC & (MJ/kg) \\
\hline WC & 43.54 & 3.59 & 51.71 & 0.16 & 1.00 & 88.07 & 10.77 & 1.16 & 11.40 & 18.09 \\
\hline CF & 40.02 & 6.03 & 53.27 & 0.54 & 0.14 & 62.37 & 17.76 & 7.92 & 11.95 & 15.22 \\
\hline
\end{tabular}


Table 2. Chemical composition of the selected limestone [20].

\begin{tabular}{|l|l|}
\hline Content & Composition Percentage (wt. \%) \\
\hline $\mathrm{CaO}$ & 70.91 \\
\hline $\mathrm{MgO}$ & 16.80 \\
\hline $\mathrm{SiO}_{2}$ & 2.19 \\
\hline $\mathrm{Al}_{2} \mathrm{O}_{3}$ & 4.43 \\
\hline
\end{tabular}

\subsection{Experimental Setup}

A batch feed downdraft gasifier was used for catalytic co-gasification. The schematic of the experimental setup is shown in Figure 1. The gasifier consists of a cylindrical body with an internal diameter of $300 \mathrm{~mm}$ and a height of $1505 \mathrm{~mm}$, with a capacity of $33.6 \mathrm{~kW}$ thermal output. The temperature of the gasifier was monitored by using six Type-K thermocouples, which were mounted at the wall of the gasifier with an interval of $215 \mathrm{~mm}$. Thermocouples were plugged into a USB (universal serial bus) data logger and data readings were recorded at every 30 seconds intervals and were stored in the computer. Air was supply to the gasifier, with a commercial vortex blower of $360 \mathrm{~L} / \mathrm{min}$ nominal flow rate and working pressure of $16 \mathrm{kPa}$ was used. The flow rate of the inlet air was controlled by using rotameter. X-Stream X2GP gas analyzer was used for syngas analysis. A gas flare point was provided on the outlet piping in order to check the combustibility of the synthesis gases and to burn poisonous gases such as $\mathrm{CO}$ before being released to the environment.

\subsection{Experiment Procedure}

The catalyst was placed at the grate of the gasifier. The catalyst loading used, was varying as $30 \%, 50 \%$, and $70 \%(\mathrm{w} / \mathrm{w})$ of the feedstock. Then gasifier was filled with $14 \mathrm{~kg}$ of blended feedstock of WC and CF. Blending ratio and weight of batch were considered constant for all co-gasification experiments. Scrap paper and an ignition lighter were used to start ignition from ignition hole. After ignition, the hole was closed and the air was supplied the blower through the air inlet pipe. The airflow rate was adjusted and controlled by using a rotameter and valve. The temperature was measured using thermocouples and data was being recorded by a data logger and computer. For syngas analysis, the sample gas was tapped from the syngas outlet pipe and then was pumped to the gas cooling and cleaning system before it was supplied to the gas analyzer. The gas analyzer was connected to the computer with a local internet connection and the composition of the gas was recorded in the computer. The remaining syngas was flared at the flare points.

Once the feedstock was fully consumed, the process was stopped and the gasifier was allowed to cool down. Char and ash were collected from the ash box and on the grate. In order to determine the carbon conversion efficiency of the process, weight measurements of the ash and char were made by using Ohaus precision standard weighing balance. 


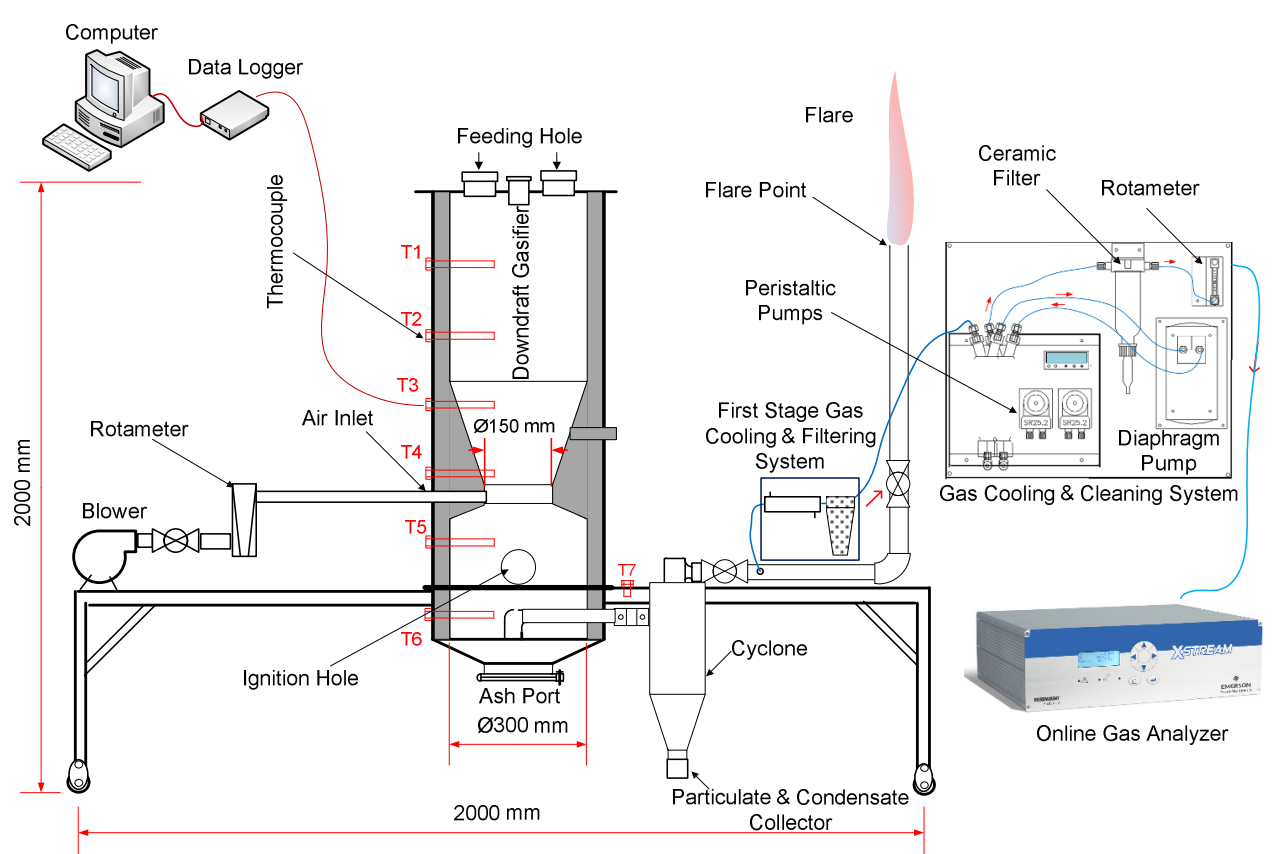

Fig. 1. Schematic of experimental setup.

\subsection{Data Interpretation and Calculation}

The average syngas composition, higher heating value, gas yield and carbon conversion efficiency were applied to evaluate the performance of the catalytic co-gasification. The higher heating value of syngas was calculated by using empirical formula given by [12]:

$$
\mathrm{HHV}_{\text {Syngas }}=12.63 \times \mathrm{X}_{\mathrm{CO}}+12.74 \times \mathrm{X}_{\mathrm{H}_{2}}+39.82 \times \mathrm{X}_{\mathrm{CH}_{4}}
$$

where, $\mathrm{XCO}, \mathrm{XH}_{2}$ and $\mathrm{XCH}_{4}$ are volume percentage of gas field. Gas yield from the gasification was calculated by [21]:

$$
\mathrm{Y}=\frac{\mathrm{Q}_{\mathrm{a}} \times 79 \%}{W_{b}\left(1-\mathrm{X}_{\mathrm{ash}}\right) \mathrm{N}_{2} \%} \mathrm{Nm}^{3} / \mathrm{kg}
$$

where, $\mathrm{Y}\left(\mathrm{Nm}^{3} / \mathrm{kg}\right)$ is the gas yield, $Q_{a}$ is the flow rate of air $\left(\mathrm{Nm}^{3} / \mathrm{hr}\right), W_{b}$ is the flow rate of biomass $\left(\mathrm{kg} / \mathrm{hr}\right.$ ), $\mathrm{X}_{\text {ash }}$ is ash content in biomass (weight \%) and $\mathrm{N}_{2} \%$ is the volumetric percentage of nitrogen in the dry syngas. It was assumed that air composition consists of $21 \%$ oxygen and $79 \%$ nitrogen, furthermore all the oxygen in air reacts with feedstock during gasification process. In addition, syngas was consists of $\mathrm{CO}, \mathrm{H}_{2}, \mathrm{CO}_{2}, \mathrm{CH}_{4}$ and $\mathrm{N}_{2}$, contents, where $\mathrm{N}_{2}$ was determined by balanced.

Carbon conversion rate of each experiment was calculated by using the formula given by:

$$
\eta_{c}=\frac{Y\left(\mathrm{CO} \%+\mathrm{CO}_{2} \%+\mathrm{CH}_{4} \%\right) \times \mathrm{Mc}}{22.4 \times \mathrm{C} \%} \times 100
$$

where, $\mathrm{C} \%$ is the mass percentage of carbon in the feedstock obtained from the ultimate analysis. $Y$ is gas yield in $\mathrm{Nm}^{3} / \mathrm{kg}$, where, \% denotes volumetric percentage of $\mathrm{CO}, \mathrm{CO}_{2}$ and $\mathrm{CH}_{4}$ in syngas. $\mathrm{Mc}$ is the atomic mass of carbon atom in grams and 22.4 is the volume of one mole of an ideal gas in litres at standard temperature and pressure. 


\section{Results and Discussion}

\subsection{Steady Operation}

Experimental results for batch fed operation of a downdraft gasifier are presented in this section. Figure 2. shows the gas composition on volume percent at different catalyst addition $0 \%, 30 \%, 50 \%$ and $70 \%$. Unlike continuous feed operation, the results for syngas composition show variation with operation duration for the case of batch fed operation due to sharp increase during start-up and decrease near the end of the operation due to depletion of the feedstock. From Figure 2b, it can be seen that CO increased from $0 \%$ to $20 \%$ within the first $10^{\text {th }}$ minutes. After the $10^{\text {th }}$ minutes of operation, it is observed that the gas composition of the gasification is found to be stabilized until the $30^{\text {th }}$ minutes. The decrease in gas composition after the $30^{\text {th }}$ minutes of operation was caused due to the batch fed operation, whereby most of the feedstock was consumed near the end of the experimental run. Therefore, the time interval between $10^{\text {th }}$ and $30^{\text {th }}$ minutes of operation could be taken as the stable duration of operation.
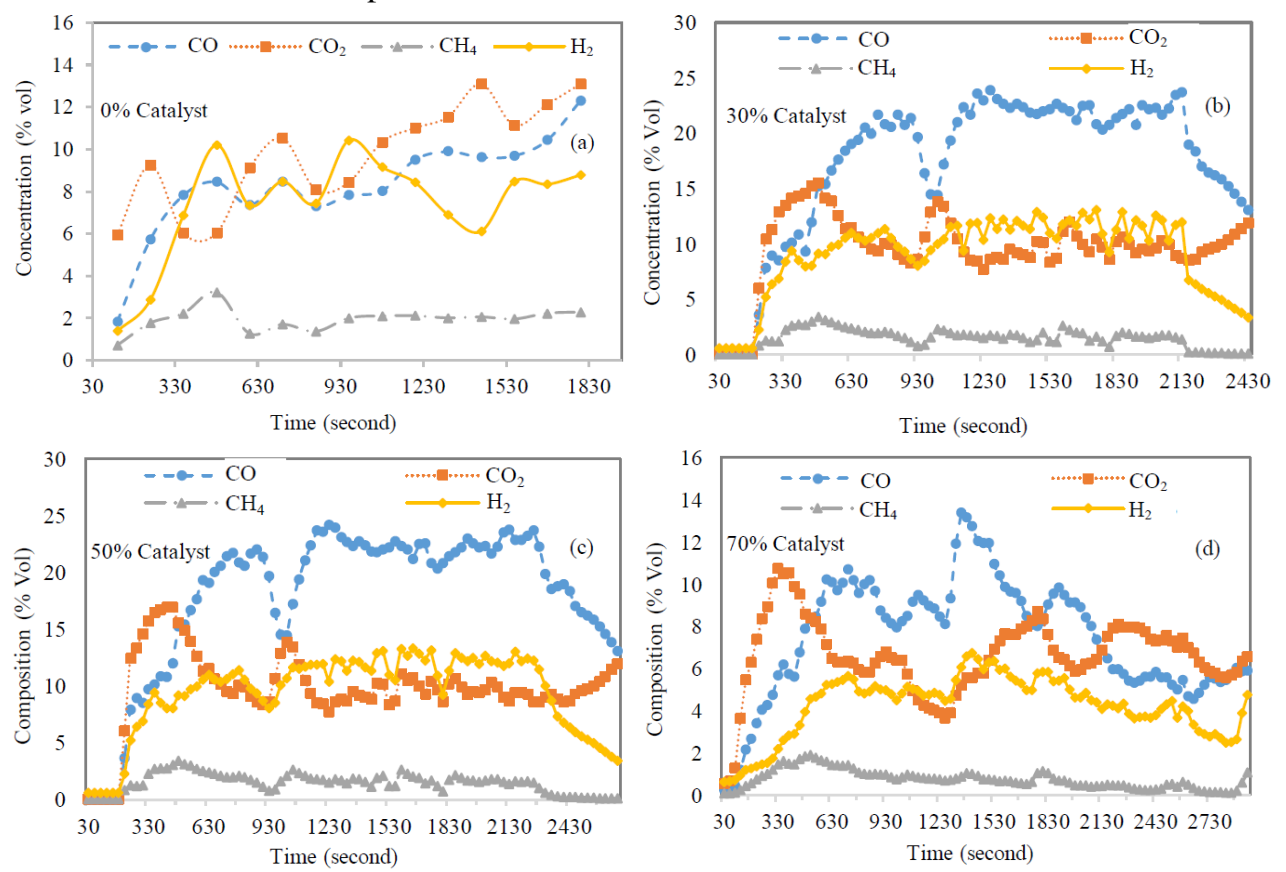

Fig. 2. Gas composition at various catalyst loading (a) $0 \%$, (b) $30 \%$, (c) $50 \%$, and (d) $70 \%$.

\subsection{Effect of Limestone Catalyst on Gas Composition and Gas Yield}

In this work, limestone was used as catalyst for gasification. The effect of the catalyst was studied for the airflow rate at 360 liter per minute and air as the gasifying medium. It can be seen that each component of gas composition was higher when catalyst was used. This observation was in line with [13, 15, 18, 22]. Figure 3(a) indicates that the presence of limestone clearly encourage the production of $\mathrm{H}_{2}$ and $\mathrm{CO}$, while the content of $\mathrm{CH}_{4}$ and $\mathrm{CO}_{2}$ slightly decreased with increasing catalyst loading [23]. At $0 \%$ catalyst, $\mathrm{H}_{2}$ was amounted to $7.32 \%$ and $\mathrm{CO}$ was about $9.35 \%$. When $30 \%$ catalyst was introduced, $\mathrm{H}_{2}$ content was amounted to $9.04 \%$ and $\mathrm{CO}$ was about $17.38 \%$. The optimum amount of $\mathrm{H}_{2}$ was produced 
when $50 \%$ catalyst was added to the gasification, which amounted to $11.39 \%$, and CO was $17.88 \%$. At $70 \%$ catalyst, $\mathrm{H}_{2}$ and $\mathrm{CO}$ content were low due to the improper airflow as too much of limestone had blocked the airflow passage. The $\mathrm{H}_{2}$ content has increased $28.3 \%$ from that as in the non-catalytic gasification. The quantity of $\mathrm{CO}_{2}$ was found to be higher than that obtained from the non-catalyzed case. With increased catalyst loading from $0 \%$ to $50 \%$, higher content of $\mathrm{CO}_{2}$ was obtained due to the release of $\mathrm{CO}_{2}$ from limestone. The reforming reaction of tar on a limestone surface by capturing carbon to produce more $\mathrm{H}_{2}$ and $\mathrm{CO}$, according to reaction Eq.(4) [12]. Besides Figure 3(b) shows that addition of catalyst has favored the gas yield. Gas yield indicates the ability of feedstock converted into gaseous products. Generally, gas yield shows the amount of gas in normal cubic meter produced by one kilogram of biomass. At non-catalytic gasification gas yield was $1.38 \mathrm{Nm}^{3} / \mathrm{kg}$ and has increased $21.78 \%$ up to $1.68 \mathrm{Nm}^{3} / \mathrm{kg}$ at $50 \%$ of catalyst addition.

$$
\mathrm{C}_{\mathrm{n}} \mathrm{H}_{\mathrm{m}}+\mathrm{nCO}_{2} \stackrel{\text { Limestone }}{\longrightarrow} 2 \mathrm{nCO}+\left(\frac{\mathrm{m}}{2}\right) \mathrm{H}_{2}
$$
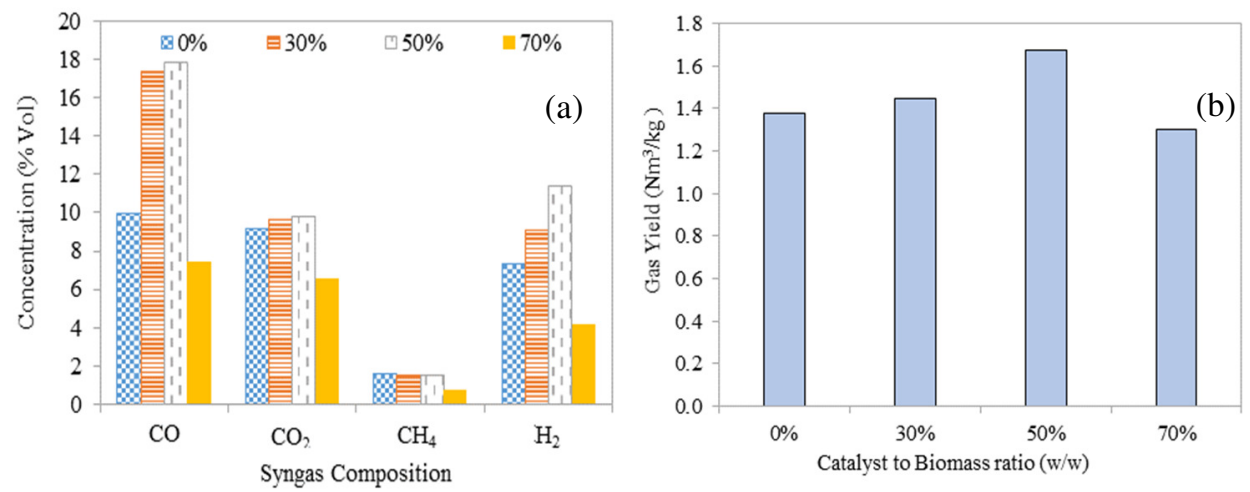

Fig.3. (a) Average syngas composition and (b) gas yield at various catalyst loading.

\subsection{Effect of Limestone Catalyst Heating Value and Carbon Conversion Efficiency}

The Figure 4a shows effect of catalyst loading on the syngas heating value. Syngas heating value was $2.82 \mathrm{MJ} / \mathrm{Nm}^{3}$ at non-catalytic gasification and the syngas heating value is between $1.96 \mathrm{MJ} / \mathrm{Nm}^{3}$ and $5.11 \mathrm{MJ} / \mathrm{Nm}^{3}$ at catalytic gasification and this value is similar to results of other studies (4-6 MJ/ $\mathrm{Nm}^{3}$ ) derived from bamboo biomass gasification [24]. The syngas heating value has increased $81 \%$ at catalytic gasification. However, at $70 \%$ catalyst loading, syngas heating value was low due to the poor airflow rate, whereby the huge amount of catalyst has blocked the air passage. The syngas heating value was significantly enhanced due to addition of limestone, and this is related to the higher reaction rate of hydrocarbon reforming [25]. Furthermore, the chemical composition of feedstock could influence the syngas fraction and heating value in biomass gasification. That is because the $\mathrm{H}$ and $\mathrm{O}$ elements might have competed to react with $\mathrm{C}$ in biomass matrix to form the $\mathrm{CH}_{4}$ or $\mathrm{CO}$. In general, the $\mathrm{CH}_{4}$ heating value is higher than $\mathrm{CO}$. Therefore, the higher $\mathrm{H}_{2}$ exhibits the higher syngas heating value. 

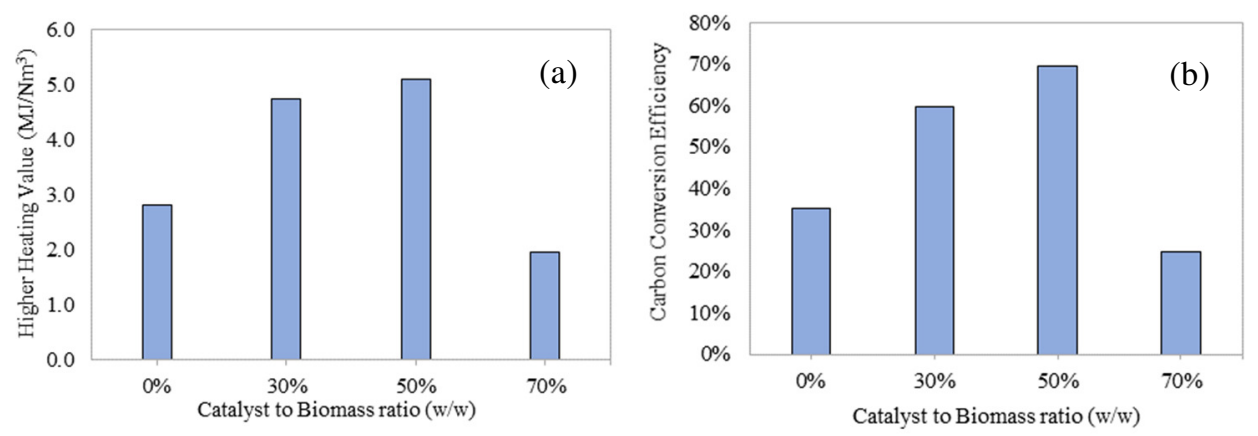

Fig. 4. (a) Syngas higher heating value (b) carbon conversion efficiency at various catalyst loading.

Mass conversion efficiency is an important parameter that determines the amount of solid feed in percentage converted to permanent gases. High mass conversion efficiency means low generation of unwanted products such as tar, char and ash. Carbon conversion efficiencies indicates how much of the initial carbon content of fuel is converted to gaseous product, and thus affecting the amount of unconverted carbon in char and tar by products from gasification. Figure $4 \mathrm{~b}$ shows the variation of carbon conversion efficiencies with different catalyst loadings. At non-catalytic gasification the carbon conversion efficiency was $35.20 \%$ and then increased sharply to $59.69 \%$ when $30 \%$ of catalyst was introduced to the gasification process. The maximum value of carbon conversion efficiencies of $69.49 \%$ was observed for the $50 \%$ of catalyst addition. The minimal value of carbon conversion efficiencies occurred at $70 \%$ catalyst loading, around $24.72 \%$ could be attributed to the blockage of catalyst at the gasifier's grate. Airflow rate was disrupted thus most of the feedstock were not burnt completely, therefore the conversion efficiency was low. These values of carbon conversion efficiencies obtained for $\mathrm{WC}$ and $\mathrm{CF}$, were found to be comparable with the results for gasification of rice husk which were reported to be $55-81 \%$ [26]. The high mass and carbon conversion efficiency of WC and CF which could be mainly due to its low ash and fixed carbon composition which showed its high potential as a fuel for thermal conversion processes.

\section{Conclusions}

Catalytic co-gasification of blended feedstock of $70 \%$ wood chips and $30 \%$ coconut fronds was carried out in a downdraft gasifier using limestone as primary catalyst. The effect of catalyst loading was investigated on syngas composition, gas yield, and carbon conversion efficiency and heating value of syngas. The catalyst loading varies as $0 \%, 30 \%, 50 \%$ and $70 \%$. The optimum catalyst loading (50\%) showed that high syngas concentration of fuel components, $\mathrm{H}_{2}, \mathrm{CO}$ and $\mathrm{CH}_{4}$. The maximum $\mathrm{H}_{2}, \mathrm{CO}$, syngas heating value, gas yield, carbon conversion efficiency were $11.39 \%, 17.88 \%, 5.11 \mathrm{MJ} / \mathrm{Nm}^{3}, 1.68 \mathrm{Nm}^{3} / \mathrm{kg}$ and $69.49 \%$ respectively. However, high catalyst loading $(70 \%)$ is not suitable for downdraft gasifier. The results of current study were found to be comparable with results of past gasification studies of woody biomass. The results showed that WC and CF blend have a high potential as a fuel for gasification. It is proposed that in future different catalyst will be investigated for cogasification of different biomass for better understanding of biomass to catalyst interaction during co-gasification. 


\section{References}

1. M. Inayat, S. A. Sulaiman, A. Kumar, and F. M. Guangul, J. Mech. Eng. Sci. 10(2), 2187-2199 (2016).

2. M. Inayat, S. A. Sulaiman, and K. Sanaullah, Effect of Blending Ratio on Co-Gasification Performance of Tropical Plant-Based Biomass, in 4th IET Clean Energy Technol. Conf. (CEAT 2016) pp. 1-7 (2016).

3. S. A. Sulaiman, M. Inayat, H. Basri, F. M. Guangul, and S. M. Atnaw, J. Mech. Eng. Sci. 10(2), 2176-2186 (2016).

4. S. A. Sulaiman, S. Balamohan, M. N. Z. Moni, S. M. Atnaw, and A. O. Mohamed, J. Mech. Eng. Sci. 9, 1744-1757 (2015).

5. S. A. Sulaiman, M. F. Karim, M. N. Z. Moni, and S. M. Atnaw, Asian J. Sci. Res. 6(2), 245 (2013).

6. K. Li, R. Zhang, and J. Bi, Int. J. Hydrogen Energy 35(7), 2722-2726 (2010).

7. K. S. Seshadri and A. Shamsi, Ind. Eng. Chem. Res. 37(10), 3830-3837 (1998).

8. M. Inayat, S. A. Sulaiman, A. Abd Jamil, F. M. Guangul, and S. M. Atnaw, The Study of Temperature Profile and Syngas Flare in Co-Gasification of Biomass Feedstock in Throated Downdraft Gasifier, in ICGSCE 2014: Proceedings of the International Conference on Global Sustainability and Chemical Engineering pp. 203-210, (2015).

9. S. A. Sulaiman, S. M. Atnaw, and A. R. Japar, Study on Co-Gasification of Oil Palm Fronds and Wood, in 2014 Int. Renew. Sustain. Energy Conf. pp. 536-541 (2014).

10. M. Inayat, S. A. Sulaiman, and J. C. Kurnia, MATEC Web Conf. 131, 3015 (2017).

11. S. A. Sulaiman, R. Roslan, M. Inayat, and M. Yasin Naz, J. Energy Inst. 91(5), 779-785 (2018).

12. P. Basu, Biomass Gasification and Pyrolysis : Practical Design and Theory (2010).

13. A. Demirbaş, Energy Convers. Manag. 43(7), 897-909 (2002).

14. F. M. Guangul, S. A. Sulaiman, and A. Ramli, Renew. Energy 72, 271-283 (2014).

15. P. Lv, Z. Yuan, C. Wu, L. Ma, Y. Chen, and N. Tsubaki, Energy Convers. Manag. 48(4), 11321139 (2007).

16. D. Sutton, B. Kelleher, and J. R. H. Ross, Fuel Process. Technol. 73(3), 155-173 (2001).

17. M. Inayat, S. A. Sulaiman, and J. C. Kurnia, J. Energy Inst. (2018).

18. K.-Y. Chiang, C.-H. Lu, and K.-L. Chien, Int. J. Hydrogen Energy 36(21), 14186-14194 (2011).

19. B. Aydinli and A. Caglar, Fuel Process. Technol. 93(1), 1-7 (2012).

20. M. N. Salleh, F. H. Kasim, K. N. Ismail, C. Mohd, and R. Ghazali, Characterization and Application of Dolomite Rock in Perlis, in Proc. 1st Int. Conf. Nat. Resour. Eng. Technol. (July), pp. 465-470 (2006).

21. F. M. Guangul, S. A. Sulaiman, and A. Ramli, Bioresour. Technol. 126, 224-232 (2012).

22. J. M. Encinar, F. J. Beltran, A. Ramiro, and J. F. Gonzalez, Fuel Process. Technol. 55(3), 219233 (1998).

23. B. Moghtaderi, Fuel 86(15), 2422-2430 (2007).

24. K.-Y. Chiang, Y.-S. Chen, W.-S. Tsai, C.-H. Lu, and K.-L. Chien, Int. J. Hydrogen Energy 37(18), 13737-13745 (2012).

25. L. Han, Q. Wang, Y. Yang, C. Yu, M. Fang, and Z. Luo, Int. J. Hydrogen Energy 36(8), 48204829 (2011).

26. K. G. Mansaray, A. E. Ghaly, A. M. Al-Taweel, F. Hamdullahpur, and V. I. Ugursal, Biomass and bioenergy 17(4), 315-332 (1999). 